Delft University of Technology

\title{
Fatigue Testing of Transversely Prestressed Concrete Decks
}

Lantsoght, Eva; van der Veen, Cor; Koekkoek, Rutger; Sliedrecht, Henk

DOI

10.14359/51715569

Publication date

2019

Document Version

Accepted author manuscript

Published in

ACI Structural Journal

\section{Citation (APA)}

Lantsoght, E., van der Veen, C., Koekkoek, R., \& Sliedrecht, H. (2019). Fatigue Testing of Transversely

Prestressed Concrete Decks. ACI Structural Journal, 116(4), 143-153. https://doi.org/10.14359/51715569

\section{Important note}

To cite this publication, please use the final published version (if applicable).

Please check the document version above.

\section{Copyright}

Other than for strictly personal use, it is not permitted to download, forward or distribute the text or part of it, without the consent of the author(s) and/or copyright holder(s), unless the work is under an open content license such as Creative Commons.

\section{Takedown policy}

Please contact us and provide details if you believe this document breaches copyrights.

We will remove access to the work immediately and investigate your claim. 
${ }^{1}$ Concrete Structures, Delft University of Technology, Delft, The Netherlands

$5 \quad{ }^{2}$ Universidad San Francisco de Quito, Quito, Ecuador

$6 \quad{ }^{3}$ Adstren, Quito, Ecuador

$7 \quad{ }^{4}$ BAM Infraconsult, Gouda, the Netherlands

$8 \quad{ }^{5}$ Rijkswaterstaat, Ministry of Infrastructure and the Environment, Utrecht, the Netherlands

9 Biography: ACI member Eva Lantsoght is a full professor at Universidad San Francisco de Quito,

10 a researcher at Delft University of Technology, The Netherlands, and a structural engineer at 11 Adstren, Ecuador. She is a member of ACI 445-0D Shear Databases, ACI-ASCE 421 Design of 12 Reinforced Concrete Slabs, ACI 342 Evaluation of Concrete Bridges and Bridge Elements, and an 13 associate member of ACI 437 Strength Evaluation of Existing Concrete Structures, and ACI-ASCE $14 \quad 445$ Shear and Torsion.

15 Cor van der Veen is an associate professor at Delft University of Technology, Delft, The 16 Netherlands. He received his MSc and $\mathrm{PhD}$ from Delft University of Technology. He is a member of various National Committees. His research interests include (very) high strength (steel fiber) concrete, concrete bridges and computational mechanics.

19 Rutger Koekkoek is a maritime engineer at BAM Infraconsult. Formerly he was a researcher at Delft University of Technology where he prepared and executed several outdoor load tests and did 21 fatigue tests on transversally precast bridge decks and shear tests on prestressed beams.

22 Henk Sliedrecht is a senior consultant at Rijkswaterstaat, Ministry of Infrastructure and 23 Watermanagement, Utrecht, The Netherlands. He received his MSc from Delft University of 24 Technology. His research interests include the assessment of existing concrete bridges in particular methods of analysis and standards for structural safety. 
ABSTRACT

2 In the Netherlands, slab-between-girder bridges with prestressed girders and transversely

3 prestressed decks in between the girders require assessment. Static testing showed that compressive

4 membrane action increases the capacity of these structures and that the decks fail in punching shear.

5 The next question is if compressive membrane action also increases the capacity of these decks

6 under repeated loads. Therefore, the same half-scale bridge structure as used for the static tests was

7 subjected to repeated loads at different fractions of the maximum static load, different loading

8 sequences, and for single and double concentrated loads. A relationship between the load level and

9 number of cycles at failure ( $S-N$ curve) for the assessment of these bridges is proposed, but the

10 influence of the loading sequence was not successfully quantified yet. The conclusion of the

11 experiments is that compressive membrane action enhances the punching capacity of transversely

12 prestressed thin decks subjected to repeated loads.

13

14 Keywords: Bridge evaluation; Compressive membrane action; Concrete bridges; Fatigue; Fatigue

15 testing; Laboratory testing; Prestressed concrete; Punching shear. 
2 During the decades following the Second World War, the Dutch road network underwent rapid expansion. Many existing bridges in the highway network have now been in service for fifty years or more. These bridges were designed according to the codes of that era. Nowadays, these bridges should be assessed according to the live loads as prescribed by the current code NEN-EN 19912:2003 (CEN, 2003). This code reflects current traffic loads and volumes, which have increased over the past decades. On the other hand, the resulting design capacity for shear and punching shear in the Eurocode NEN-EN 1992-1-1:2005 (CEN, 2005) is lower than the design shear and punching shear capacity that was prescribed by the Dutch National codes. For reinforced concrete slab bridges, the shear capacity is often found to be insufficient upon assessment according to the current

11 codes (Lantsoght et al., 2013). For existing slab-between-girder bridges consisting of post-tensioned 12 girders and thin transversely prestressed concrete decks, the punching shear capacity is often found 13 to be insufficient upon assessment according to the current codes. The span to depth ratio of the decks in these bridges is larger than 10 , so that the contributions of the shear deformations are negligible, and the deck can be considered as thin.

The subset of slab-between-girder bridges in the Netherlands consists of about seventy

17 bridges (Koekkoek et al., 2018). The punching shear capacity from NEN-EN 1991-2:2003 (CEN, 18 2003) is an empirical expression, derived from tests on slab-column connections (Mitchell et al., 19 2005; Regan and Braestrup, 1985). These test elements have a different structural behaviour from 20 the slabs in slab-between-girder bridges. In these structures, additional sources of capacity can 21 increase the capacity; in particular compressive membrane action, which can develop when 22 sufficient lateral restraint exists (Amir, 2014; Hon et al., 2005; Kirkpatrick et al., 1986; Kuang and 23 Morley, 1992; 1993; Taylor et al., 2007; Tong and Batchelor, 1972). The transverse prestressing in these deck slabs further enhances the capacity (Marshe and Green, 1999). 
1 between-girder bridges, Amir (Amir, 2014) carried out static tests on a half-scale model of an

2 existing slab-between-girder bridge (Amir et al., 2016). A test specimen was built consisting of four

3 prestressed girders, prestressed concrete transverse beams, and a transversely prestressed concrete

4 deck (Amir et al., 2016), see Fig. 1. The 19 experiments on this specimen quantified the ultimate

5 capacity of these decks as part of a realistic bridge structure. The variables in the experiments were

6 the position of the load, the details of the joint between the deck and girders, the difference between

7 a single and a double wheel load, and the amount of transverse prestressing. The deck failed in

8 punching shear for all experiments. The test results were compared to the mean punching shear

9 capacity from prENV 1992-1-1:2002 (Walraven, 2002), which lies at the basis of the design

10 punching shear capacity in NEN-EN 1992-1-1:2005 (CEN, 2005). This comparison showed an

11 average tested-to-predicted capacity of 2.32 (Amir, 2014).

12 To consider the beneficial effect of compressive membrane action for the assessment of

13 existing Dutch slab-between-girder bridges in assessment, it needs to be proven first that this

14 mechanism also occurs under repeated loading. He (1992) also raised this concern. For this purpose,

15 fatigue tests are carried out on the same half-scale model of an existing slab-between-girder bridge

16 as used for the static tests. Practicing engineers have also reported their concerns regarding the

17 fatigue capacity of bridge slabs (Low, 2011).

\section{RESEARCH SIGNIFICANCE}

20 Laboratory experiments are typically carried out on structural members and not on structural

21 systems. For fatigue testing, previous research has focused more on materials subjected to cyclic

22 loading than structural elements. The presented fatigue experiments on a half-scale model of a

23 complete bridge structure give insight in the behavior and capacity of slab-between-girder

24 prestressed concrete bridges, and in particular the effect of fatigue on compressive membrane

25 action. As such, the presented experiments provide a novel insight in the behavior of bridge systems 
1 under fatigue loading. The results can be used for an improved assessment of existing slab-between-

2 girder bridges.

\section{FATIGUE STRENGTH OF CONCRETE STRUCTURES}

4 The effect of fatigue on concrete structures is typically first studied based on the effect of cycles of

5 loading on the material properties (CEB Committee GTG 15, 1988; Hordijk, 1991): concrete

6 compressive (Bennett and Muir, 1967; Lantsoght et al., 2016) and tensile strength (Hordijk et al.,

7 1995; Hsu, 1981; Wang and Song, 2011; Yu et al., 2014), and reinforcing and prestressing steel

8 strength (Mander et al., 1994; Tilly, 1979; Tilly, 1984). The reduction of the material strength is

9 expressed as a function of the number of applied cycles, which results in the so-called Wöhler-curve

10 or $S$ - $N$ curve (with $S$ the fraction of the static strength and $N$ the number of cycles). These relations

11 are developed based on experimental results. Some material models for fatigue assume an

12 endurance limit (Arora and Singh, 2016; Lee and Barr, 2004; Saucedo et al., 2013; Yin and Hsu,

13 1995), which means that no further reduction of $S$ occurs after a certain number of cycles (for

14 example: $2 \times 10^{6}$ ).

Experiments on structural elements under fatigue loading representative of traffic loads on bridges are not very common. The influence of cycles of loads that represent seismic actions has

17 been studied experimentally (El-Bahy et al., 1999; Mander et al., 1994; Manfredi and Pecce, 1997;

18 Marthong et al., 2016; Thomson et al., 1998). Such experiments use loads that result in stress 19 reversals, a situation which is different from what happens in a bridge subjected to repeated traffic 20 loads (Elfgren, 2015; Forrest et al., 2010; Schlafli and Bruhwiler, 1998).

In the literature, fatigue experiments on isolated structural members are reported. Of interest here are the experiments on shear-critical structures. Experiments are reported on the fatigue life of 23 deep beams (Isojeh et al., 2017; Teng et al., 1998), the fatigue life of shear-critical concrete beams 24 (Gallego et al., 2014; Hawkins, 1974; Hegger et al., 2015; Liu et al., 2018; Muller and Dux, 1994; 
1 1958; Ueda, 1983; Yuan et al., 2017), and the fatigue life of shear-critical slabs (Fujiyama et al.,

2 2008). The tests on slabs showed that the fatigue life under a moving load is lower than for a load

3 that is repeatedly applied at the same position (Sonoda and Horikawa, 1982). For partially

4 prestressed concrete beams (Harajli and Naaman, 1985; Naaman and Founas, 1991; Shahawi and

5 Batchelor, 1986; Xin et al., 2015; Xin et al., 2017; Zeng et al., 2014), experiments showed that the

6 failure mode could change from flexural failure to shear failure, which led to thorough research on

7 this topic.

Furthermore, experiments are used to assess the fatigue life of strengthening measures on structural elements (Noël and Soudki, 2015; Oudah and El-Hacha, 2013), of new sections or materials (Larson et al., 2005; Tong et al., 2016; Younes et al., 2017; Zhang et al., 2016a), and of

11 elements with material damage or degradation (Ahmed et al., 1998; Salem, 2013; Zhang et al., 12 2016b). Probabilistic approaches can address the large scatter on the results from fatigue tests (Al13 Zaid and Nowak, 1988; Casas and Crespo-Minguillon, 1998; Juan, 2000; Rodrigues et al., 2013).

\section{EXPERIMENTAL INVESTIGATION}

\section{Test setup}

16 The fatigue experiments were carried out on the same test setup as the static tests. To be able to 17 carry out additional fatigue tests, the original central deck was removed and a new deck was cast.

18 The overall geometry of the test bridge is shown in Fig. 1. All dimensions are modelled after an

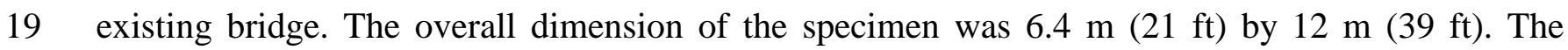

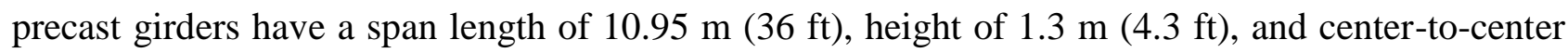

21 distance of $1.8 \mathrm{~m}(5.9 \mathrm{ft})$ and were made by a Dutch fabricator of precast prestressed concrete

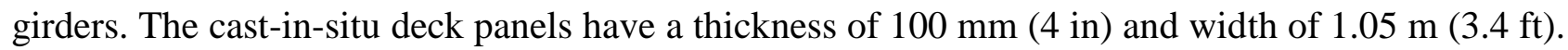

23 The cast-in-situ transverse beams have a rectangular cross-section of $810 \mathrm{~mm} \times 350 \mathrm{~mm}(32 \mathrm{in} \times 14$ in). All details of the original setup are discussed in (Amir, 2014; Amir et al., 2016). 
1 fabricator, the formwork for the transverse beams was built, the transverse beams were cast, the

2 formwork for the deck panels was built, the deck panels were cast, the steel frame for testing was

3 positioned over the model bridge, and finally the transverse beams and deck were prestressed. To

4 carry out the additional fatigue tests, slab panel B (see Fig. 1b) was removed after applying a saw

5 cut, formwork was built, and a new slab was cast again. Fig. 2a shows the setup before casting the

6 new deck and Fig. 2b shows the complete setup with the new slab panel B.

7 Material properties

8 High strength concrete is used in the scale model to be representative of the measured compressive

9 strength in an existing slab-between-girder bridge $\left(f_{c m, c u b e}=98.8 \mathrm{MPa}=14,330 \mathrm{psi}\right.$ in the deck,

10 determined on concrete core samples, see Amir (2014)). The high compressive strength in the

11 existing bridge is the result of ongoing cement hydration. Given the casting sequence in the

12 laboratory of the elements of the setup, and the fact that the prestressed girders were fabricated by a

13 prefabricator, the different values of the compressive strength are discussed here.

The concrete compressive strength of the girders at 273 days (after finishing the static experiments) as measured on $150 \mathrm{~mm}(6 \mathrm{in})$ cubes is $f_{c m, c u b e}=90 \mathrm{MPa}(13,050 \mathrm{psi})$ (Amir, 2014).

The average splitting tensile strength of the concrete is $f_{\text {ctm, cube }}=6.3 \mathrm{MPa}(914 \mathrm{psi})$ at 273 days.

The concrete compressive strength of the transverse beams is $f_{\text {cm, cube }}=71 \mathrm{MPa}(10,300 \mathrm{psi})$ measured at 28 days (Amir, 2014).

Cubes that were cast along with the deck slab are tested at different points in time. At 28 days, $f_{c m, c u b e}=75 \mathrm{MPa}(10,880 \mathrm{psi})$ for the original decks slab (Amir, 2014), and $f_{\text {cm,cube }}=68 \mathrm{MPa}$ $(9,863$ psi) measured at 28 days for the newly cast slab panel B. The average splitting tensile strength is $f_{\text {ctm, cube }}=5.4 \mathrm{MPa}(783 \mathrm{psi})$ for the original deck slab at 28 days, and $f_{\text {ctm,cube }}=5.5 \mathrm{MPa}$ 23 (798 psi) for the newly cast slab panel B at 28 days. Details about the strength development of the concrete in the original test setup are given in (Amir, 2014). For the concrete of the newly cast deck panel $\mathrm{B}$, the results of cube tests at 56 days are $f_{\text {cm,cube }}=77 \mathrm{MPa}(11,170 \mathrm{psi})$ and $f_{\text {ctm, } \text { cube }}=5.7 \mathrm{MPa}$ 
1 (827 psi), and after 188 days $f_{\text {cm,cube }}=78 \mathrm{MPa}(11,310 \mathrm{psi})$ and $f_{\text {ctm, cube }}=5.9 \mathrm{MPa}(856 \mathrm{psi})$. The

2 results of the concrete compressive strength for the cubes tested at the day of an experiment are

3 given in Table 1 for the static tests and in Table $\mathbf{2}$ for the fatigue tests.

The reinforcement steel in the girders is B500A for bars with a diameter $\leq 6 \mathrm{~mm}(0.236 \mathrm{in} \approx$ $\# 2$ bars) and $\mathrm{B} 500 \mathrm{~B}$ for bars with diameter $\geq 8 \mathrm{~mm}(0.315 \mathrm{in} \approx \# 3$ bars), which has a yield strength

6 of $f_{y} \geq 500 \mathrm{MPa}(73 \mathrm{ksi})$. For the reinforcement steel of the elements cast in the laboratory, the yield

7 strength is measured on steel samples in the laboratory as $f_{y}=525 \mathrm{MPa}(76 \mathrm{ksi})$ and the ultimate

8 tensile strength is $f_{t}=580 \mathrm{MPa}(84 \mathrm{ksi})$. The prestressing steel in the girders is Y1860S

9 (prestressing strands), which has a characteristic tensile strength $f_{p k}=1,860 \mathrm{MPa}$ (270 ksi) and the

10 prestressing steel in the slab and transverse beam is $\mathrm{Y} 1100 \mathrm{H}$ (prestressing bars), which has a

11 characteristic tensile strength $f_{p k}=1,100 \mathrm{MPa}(160 \mathrm{ksi})$.

\section{Reinforcement}

13 In total, the deck has 30 prestressing ducts with a diameter of $40 \mathrm{~mm}$ (1.6 in) and a center-to-center 14 distance of $400 \mathrm{~mm}$ (16 in). In the newly cast slab panel B, at two positions over the entire span 15 length, ducts with a diameter of $30 \mathrm{~mm}$ (1.2 in) and a spacing of $300 \mathrm{~mm}$ (12 in) are used to study 16 the influence of the duct spacing, see Fig. 3b. The deck is post-tensioned with unbonded 17 prestressing bars, to vary the level of transverse prestressing, which was a parameter studied in the 18 first series of experiments (Amir et al., 2016). For the fatigue tests, the average compressive stress 19 in the concrete deck from the transverse prestressing is $2.5 \mathrm{MPa}$ (363 psi), which is the same level 20 of transverse prestressing as used in an existing bridge. The prestressing bars in the deck have a 21 diameter of $15 \mathrm{~mm}(0.6 \mathrm{in})$. The bars are anchored with steel plates of $100 \mathrm{~mm} \times 170 \mathrm{~mm} \times 20 \mathrm{~mm}$ 22 (3.9 in $\times 6.7$ in $\times 0.8$ in).

For the reinforcing steel, the longitudinal reinforcement in the slab is diameter $6 \mathrm{~mm}(0.236$

24 in $\approx \# 2$ ) bars spaced $200 \mathrm{~mm}(7.9 \mathrm{in})$ on center top and bottom ( 5 bars in total per slab panel), and 25 the transverse reinforcement is diameter $6 \mathrm{~mm}(0.236 \mathrm{in} \approx \# 2)$ bars spaced $250 \mathrm{~mm}(9.8 \mathrm{in})$ on 
1 center top and bottom (61 bars in total per slab panel). The clear cover to the mild steel is $7 \mathrm{~mm}$

2 (0.28 in). The details of the reinforcement and prestressing of the girders, deck, and transverse

3 beams are given in (Amir, 2014).

\section{Instrumentation}

5 During the experiments, sensors measured the deflections, crack widths, and movement in the joint

6 of the bridge setup. The specimens were instrumented with 16 LVDTs and 14 laser distance finders.

7 In total, 46 load cells measure the force in the prestressing bars in the deck and the transverse

8 beams. The deflection from the top of the specimen is measured with eight laser distance finders

9 and four LVDTs, whereas the deflection at the bottom of the specimen is measured with four laser

10 distance finders. Two LVDTs monitor crack width after the occurrence of the crack in the length

11 direction. The remaining LVDTs and lasers follow the joint and movement at the supports of the

12 prestressed girders. On the original deck, two experiments were carried out for which acoustic

13 emission sensors were used as part of a research project on acoustic emission measurements.

\section{Loading procedure}

15 For the tests on the original test setup, the load is applied with a hydraulic jack on a steel plate of $16200 \mathrm{~mm} \times 200 \mathrm{~mm}(7.9 \mathrm{in} \times 7.9 \mathrm{in})$. This size is half-scale of the wheel print of the design tandem 17 used in live Load Model 1 of NEN-EN 1991-2:2003 (CEN, 2003). The design tandem has two axles 18 at a distance of $1.2 \mathrm{~m} \mathrm{(4ft)}$ with two wheel prints at $2 \mathrm{~m}(6.6 \mathrm{ft})$ distance. The load plate is $20 \mathrm{~mm}$ 19 (0.8 in) thick. For the fatigue tests on the new deck, a steel plate of $115 \mathrm{~mm} \times 150 \mathrm{~mm} \times 20 \mathrm{~mm}$ 20 (4.5 in $\times 5.9$ in $\times 0.8$ in) is used. This size is half-scale of the wheel print used in the fatigue load 21 model in the Netherlands. This load model uses the same geometry of the design tandem as Load 22 Model 1, but uses a smaller wheel print. Between the deck and the load plate, a layer of rubber of $2310 \mathrm{~mm}(0.4 \mathrm{in})$ thick is placed to avoid stress concentrations. For the static reference tests, the load 24 was applied with a monotonic loading protocol (Fig. 4a), and at certain load levels the load was 25 kept constant to inspect the specimen and mark cracks. The static tests were performed in a 
1 displacement-controlled way. For two experiments with a low number of cycles, three cycles for

2 each predetermined load level were carried out, as typical for load tests (Lantsoght et al., 2017), see

3 Fig. $4 \mathbf{b}$. For the fatigue tests, the load was cycled between a low load level $F_{\text {low }}$ and an upper load

4 level $F_{u p}$, with $F_{\text {low }}=0.1 F_{u p}$. The load is applied as a sinus function (see excerpt of 5 seconds in Fig.

5 4c) with a frequency of $1 \mathrm{~Hz}$. The influence of the frequency is not studied in these experiments,

6 and is still a topic of discussion (Lantsoght et al., 2016). The fatigue tests were performed in a

7 force-controlled way. These tests ran almost continuously, and were only paused at predetermined

8 numbers of cycles, so that the researchers could mark the cracks and report the crack development.

\section{EXPERIMENTAL RESULTS AND DISCUSSION}

\section{Test results and failure modes}

12 In total, 19 static tests (BB1 through BB19) were carried out on the original setup, and these 13 experiments are all reported elsewhere (Amir et al., 2016). Subsequently, two tests with a limited number of cycles were carried out (Fig. 4b) (BB17 and BB18), and then two fatigue tests were carried out on the original setup (BB23 and BB24). On the new deck, eight experiments in total were carried out: five dynamic tests (four with a single load and one with a double load; BB26, BB28, BB29, BB30, and BB32) and three static tests (BB25, BB27, and BB31). An overview of the number of the experiments is shown in Fig. 3a for the original setup and Fig. $\mathbf{3 b}$ for the setup with the new slab panel B. For the study of the effect of fatigue loading, four static experiments from the original series (BB1, BB2, BB7, and BB19) with a transverse prestressing of $2.5 \mathrm{MPa}$ (363 psi) are

21 analyzed together with the new experiments. Table 1 gives an overview of the main properties of the static tests. In this table, the failure load is given as $P_{\max }$ and the average cube concrete

23 compressive strength measured on concrete at the day of testing is $f_{\text {cm,cube }}$. The size of the loading plate is indicated for reference as well. 
1 cycles per load level as part of the research on the use of acoustic emission measurements. BB24

2 did not fail after 1,500,000 cycles and was then subjected to a static test of which the result is given

3 in Table 1. For the fatigue tests in which the maximum load $F$ was varied, the different load levels

4 and their respective number of cycles $N$ are reported separately in Table 2 . The values of $F / P_{\max }$ are

5 the ratio of the applied maximum load in the fatigue test $F$ to the maximum load in the

6 corresponding static test $P_{\max }$ as reported in Table 1. For experiments that lasted more than a day,

7 Table 2 gives the range of ages of the concrete between the start of the test and the end of the test,

8 and the cube concrete compressive strength $f_{c m, c u b e}$ tested at the start of the test and at the end of the

9 test. The size of the loading plate is indicated as reference as well.

10 The failure mode for all experiments is punching shear, either brittle punching (BP) or

11 flexural punching (FP). The brittle punching failure mode is characterized by a sudden failure,

12 whereas the flexural punching is characterized by a plateau in the load-deflection diagram before

13 punching occurs. Fig. 5 shows photographs of the specimens after failure.

All details of these experiments and the development of the cracks are given in the experimental report (van der Veen and Bosman, 2014). An example of the development of cracks as drawn for each experiment is shown in Fig. $\mathbf{6}$ for a selection of the predetermined number of

17 cycles at which cracks were registered. The existing cracks are shown in black, and the newly 18 observed cracks are shown in red.

\section{Distance between prestressing strands}

20 In the existing bridge after which the test setup is modeled, the difference between the transverse 21 prestressing varies between $650 \mathrm{~mm}$ (26 in) and $800 \mathrm{~mm}$ (31 in). In the laboratory setup for the first 22 series of experiments, the most unfavorable situation of $800 \mathrm{~mm}$ (31 in) was selected as a reference, 23 resulting in $400 \mathrm{~mm}$ (16 in) on the 1:2 scale model. In the newly cast deck slab panel $\mathrm{B}$, the 24 influence of the distance was studied, and a spacing of $300 \mathrm{~mm}$ (12 in) was tested as well. 
1 (74 kip) can be compared to the results of BB27 $\left(P_{\max }=364.6 \mathrm{kN}=82 \mathrm{kip}\right)$ and BB31 $\left(P_{\max }=333.0\right.$

$2 \mathrm{kN}=75 \mathrm{kip}$ ), which gives an average of $P_{\max , \text { avg }}=348.8 \mathrm{kN}$ (78 kip), for a spacing of $400 \mathrm{~mm}(16$

3 in). In conclusion, for the static tests, the influence of the distance between the transverse

4 prestressing bars on the failure load is limited.

For the fatigue tests, the results of BB26 with $300 \mathrm{~mm}$ (12 in) spacing can be analyzed. In

6 this test, failure occurred after 1,405,337 cycles with $F=165 \mathrm{kN}$ (37 kip). A comparable test is

7 BB28 with $400 \mathrm{~mm}$ (16 in) spacing between the ducts. In BB28, 1,500,000 cycles with $F=165 \mathrm{kN}$

8 (37 kip) were followed by 1,000,000 cycles with $200 \mathrm{kN}$ (45 kip), and ultimately 7,144 cycles with

$9240 \mathrm{kN}$ (54 kip). This result seems to indicate that a shorter distance between the prestressing ducts

10 is less favorable than a larger distance. This observation is contradictory to the original assumptions

11 followed when designing the test setup. However, to come to a conclusion on the effect of duct

12 spacing on fatigue strength of the concrete decks, more experiments are necessary, because the 13 scatter on fatigue tests is large.

\section{Sequence of load levels}

15 For the fatigue tests, the influence of the sequence of load levels was studied by comparing 16 experiments with high-to-low load levels to experiments with low-to-high load levels. In BB32, the 17 load was first 10,000 cycles at $240 \mathrm{kN}$ (54 kip). Then, the load was reduced to $200 \mathrm{kN}$ (45 kip), and 18 the deck punched after 272,548 cycles. In BB28, on the other hand, the first load level was $165 \mathrm{kN}$ 19 (37 kip) with 1,500,000 cycles, then $200 \mathrm{kN}$ (45 kip) in 1,000,000 cycles, and then $240 \mathrm{kN}$ (54 kip) 20 in 7,144 cycles. This observation seems to indicate that a higher load level followed by a lower load 21 level leads to a lower fatigue resistance than a lower load level followed by a higher load level. 22 Given the large scatter on fatigue tests, however, the currently presented two experiments do not 23 provide sufficient information to draw conclusions on the sequence of load levels. Therefore, it is 24 recommended to investigate this parameter and thus the validity of Miner's rule with additional 25 experiments. This influence is the topic of future research. 


\section{Single or double wheel load}

2 For the static load tests, the effect of using a single wheel load versus a double wheel load is

3 discussed in (Amir, 2014). For the tests with a double load, failure occurred by punching of one of

4 the loads through the slab. The maximum load on the two wheel prints combined is on average 1.48

5 times the load on a single wheel print.

For the fatigue tests, only one experiment with double wheel prints is available: BB30. In this experiment, the load was applied at load levels of $F / P_{\max }=0.58,0.5,0.58,0.67$, and 0.75 . The last load level is higher than any of the load levels used in the experiments with a single load. The sequence of load levels is also different. Therefore, a direct comparison with a similar experiment with a single load is not possible. It can only be remarked that the overall trend is similar when one

11 or two loads are used.

\section{RESULTING S-N CURVE}

14 Table 2 shows that for BB24, BB28, B29, BB30, and BB32, different load levels were used if failure did not occur after the first load level, resulting in a variable amplitude loading. For the analysis and development of the $S$-N curve, a conservative approach is used to take these results

17 into account. BB28 was subjected to $2,507,144$ cycles in total: $1,500,000$ at $F / P_{\max }=0.48$, $181,000,000$ at $F / P_{\max }=0.58$, and 7,144 at $F / P_{\max }=0.7$. It is conservative to assume that the specimen would have resisted $2,507,144$ cycles at $F / P_{\max }=0.48,1,007,144$ cycles at $F / P_{\max }=0.58$, and 7,144 cycles at $F / P_{\max }=0.7$. For BB30, where $F / P_{\max }=0.58$ is applied twice, the results for the two

21 applications of the same load ratio are summed. Fig. 7 shows the resulting $S-N$ curve. The 16 datapoints on this curve are the 17 entries in Table 2, without the first load level of BB30 as explained previously. The first two experiments in which three cycles of different load levels were used as part of the research on acoustic emission measurements are shown as "AE tests" in Fig. 7. 
1 slab punched, as well as the results from BB23 and BB26 in which failure occurred for the first load

2 level that was tested, are indicated as "failure" in Fig. 7. The results show a clear trend: the number

3 of cycles to failure increases as the ratio $S=F / P_{\max }$ decreases, as expected for fatigue testing.

6 The 5\% lower bound curve is:

The 95\% upper bound curve is: decks are subjected to fatigue loading. The average line in the $S-N$ curve is found using the linear least squares approximation:

$$
S=-0.062 \log N+0.910
$$

$$
S=-0.062 \log N+0.812
$$

$$
S=-0.062 \log N+1.008
$$

Fig. 7 shows the lines of the average, the 5\% lower bound, and the $95 \%$ upper bound. From the expression of the average, Eq. (1), the fatigue strength at 1 million cycles is $54 \%$ of the static strength, $48 \%$ at 10 million cycles, and $41 \%$ at 100 million cycles. These results are similar to other fatigue tests of structural concrete and the fatigue resistance of concrete under compression. As such, the results show that compressive membrane action which was found to act as an enhancement for the punching shear capacity during static tests is also activated during fatigue loading of concrete slab-between-girder bridges.

\section{SUMMARY AND CONCLUSIONS}

As a result of the introduction of the new Eurocodes, existing slab-between-girder prestressed concrete bridges in the Netherlands that were designed according to national codes require assessment. Previous research found that the maximum load on the transversely prestressed concrete decks in these bridges is larger than predicted by the governing codes as a result of compressive membrane action. To be able to apply this result to the assessment of these bridges, it must be shown that compressive membrane action occurs when transversely prestressed concrete 
To study the effect of fatigue loading on compressive membrane action, a half-scale bridge

2 was built in the laboratory. In total, four static tests were carried out in addition to the available

3 static tests from the previous research, as well as two tests with three cycles per load level, and

4 seven fatigue tests. All tests resulted in a punching shear failure.

The influence of the distance between the prestressing ducts was studied, and was found to

6 be of minor importance. Similar trends for the behavior of slabs under single wheel loads as for

7 slabs under double wheel loads were observed. The maximum total load for a double wheel print is

8 about 1.48 times the maximum load for a single wheel print. The sequence of the load levels seems

9 to indicate that using a higher load level first leads to a lower fatigue life than using a lower load

10 level first. This topic requires further experimental research.

11 From the experiments, an $S-N$ curve is developed. The relation between the load ratio and

12 the number of cycles to failure is similar as what is observed for concrete under cycles of

13 compression and concrete members under fatigue loading. As such, it is shown that compressive

14 membrane action contributes to the increased capacity of transversely prestressed concrete decks

15 when these are subjected to fatigue loading. The enhancement of compressive membrane action was

16 determined in static tests as 2.32 as compared to the punching capacity predicted by the Eurocode

17 with an empirical formula derived from slab-column connection tests.

\section{ACKNOWLEDGMENTS}

20 The authors wish to express their gratitude and sincere appreciation to the Dutch Ministry of

21 Infrastructure and the Environment (Rijkswaterstaat) for financing this research work. We are

22 deeply indebted to our colleague Albert Bosman for his work in the laboratory and the meticulous

23 reporting of the experiments. We'd also like to thank our former colleagues Sana Amir and Patrick

24 van Hemert for their contributions to the beginning of this research project. 
$2 f_{c m, c u b e}$ average measured concrete cube compressive strength

$3 f_{\text {ctm,cube }}$ average measured concrete splitting tensile strength measured on cubes

$4 f_{t} \quad$ tensile strength of the steel

$5 \quad f_{y} \quad$ yield strength of the steel

$6 \quad F \quad$ applied load

$7 \quad F_{\text {low }} \quad$ lower limit of applied load during fatigue tests

$8 \quad F_{u p} \quad$ upper limit of applied load during fatigue tests

$9 \quad N \quad$ number of cycles

$10 P_{\max }$ maximum load in experiment

$11 S \quad$ fraction of static strength

12

13 
2 Ahmed, T., Burley, E. and Rigden, S., 1998, "The static and fatigue strength of reinforced concrete

3 beams affected by alkali-silica reaction," ACI Materials Journal, V. 95, No. 4, Jul-Aug, pp. 3764388.

5 Al-Zaid, R. Z. and Nowak, A. S., 1988, "Fatigue strength of prestressed concrete girder bridges,"

6 Canadian Journal of Civil Engineering, V. 15, No. 2, pp. 199-205.

7 Amir, S., 2014, "Compressive Membrane Action in Prestressed Concrete Deck Slabs," Ph.D. Thesis, $8 \quad$ Delft University of Technology, pp. 317.

9 Amir, S., Van der Veen , C., Walraven, J. C. and de Boer, A., 2016, "Experiments on Punching 10 Shear Behavior of Prestressed Concrete Bridge Decks," ACI Structural Journal, V. 113, No. 3, pp. $11 \quad 627-636$.

12 Arora, S. and Singh, S. P., 2016, "Analysis of flexural fatigue failure of concrete made with $100 \%$ 13 Coarse Recycled Concrete Aggregates," Construction and Building Materials, V. 102, 2016/01/15/, 14 pp. 782-791.

15 Bachman P.M., Kreger, M.E. and Breen, J. E., 1987, "An exploratory investigation of shear fatigue 16 behavior of prestressed concrete girders," Research Report 465-1, The University of Texas at 17 Austin, 198 pp.

18 Bennett, E. W. and Muir, S. E. S. J., 1967, "Some fatigue tests of high-strength concrete in axial 19 compression," Magazine of Concrete Research, V. 19, No. 59, pp. 113-117.

20 Casas, J. R. and Crespo-Minguillon, C., 1998, "Probabilistic response of prestressed concrete 21 bridges to fatigue," Engineering Structures, V. 20, No. 11, pp. 940-947.

22 Casas, J.R., 2000, "Safety of Prestressed Concrete Bridges to Fatigue: Application to Serviceability 23 Limit State of Decompression," ACI Structural Journal, V. 97.

24 CEB Committee GTG 15, 1988, "Fatigue of Concrete Structures," CEB Bulletin d'information No 25188. 
1 CEN, 2003, "Eurocode 1: Actions on structures - Part 2: Traffic loads on bridges, NEN-EN 1991-

2 2:2003," Comité Européen de Normalisation, Brussels, Belgium, 168 pp.

3 CEN, 2005, "Eurocode 2: Design of Concrete Structures - Part 1-1 General Rules and Rules for 4 Buildings. NEN-EN 1992-1-1:2005," Comité Européen de Normalisation, Brussels, Belgium, 229 5 pp.

6 El-Bahy, A., Kunnath, S. K., Stone, W. C. and Taylor, A. W., 1999, "Cumulative Seismic Damage 7 of Circular Bridge Columns: Benchmark and Low-Cycle Fatigue Tests," Structural Journal, V. 96, $8 \quad$ No. 4.

9 Elfgren, L., 2015, "Fatigue Capacity of Concrete Structures: Assessment of Railway Bridges," 10 Lulea University of Technology.

11 Forrest, R. W. B., Higgins, C. and Senturk, A. E., 2010, "Experimental and Analytical Evaluation of 12 Reinforced Concrete Girders under Low-Cycle Shear Fatigue," ACI Structural Journal, V. 107, No. 13 2, March-April 2010, pp. 199-207.

14 Fujiyama, C., Gebreyouhannes, E. and Maekawa, K., 2008, "Present Achievement and Future 15 Possibility of Fatigue Life Simulation Technology for RC Bridge Deck Slabs," Society for Social 16 Management Systems Internet Journal, V. 4, No. 1.

17 Gallego, J. M., Zanuy, C. and Albajar, L., 2014, "Shear fatigue behaviour of reinforced concrete 18 elements without shear reinforcement," Engineering Structures, V. 79, pp. 45-57.

19 Harajli, M. H. and Naaman, A. E., 1985, "Static and Fatigue Tests on Partially Prestressed Beams," 20 Journal of Structural Engineering, V. 111, No. 7, pp. 1602-1618.

21 Hawkins, N. M., 1974, "Fatigue Characteristics in Bond and Shear of Reinforced Concrete Beams," ACI Special Publication SP-41 Fatigue of Concrete.

23 He, W., 1992, "Punching behaviour of composite decks with transverse prestressing," Ph.D Thesis, 24 Queen's University, Ontario, Canada.

25 Hegger, J., Marzahn, G., Teworte, F. and Herbrand, M., 2015, "Principal tensile stress criterion for 
1 the shear assessment of existing concrete bridges," Beton- und Stahlbetonbau, V. 110, No. 2, pp. $282-95$.

3 Hon, A., Taplin, G. and Al-Mahaidi, R. S., 2005, "Strength of reinforced concrete bridge decks

4 under compressive membrane action," ACI Structural Journal, V. 102, No. 3, May-Jun, pp. 3935401.

6 Hordijk, D. A., 1991, "Local approach to fatigue of concrete," Ph.D. Thesis, Delft University of 7 Technology, Delft, the Netherlands, pp.

8 Hordijk, D. A., Wolsink, G. M. and Vries, J. d., 1995, "Fracture and fatigue behaviour of a high 9 strength limestone concrete as compared to gravel concrete," Heron, V. 40, No. 2, pp. 125-146.

10 Hsu, T. T. C., 1981, "Fatigue of plain concrete," Journal of the American Concrete Institute, V. 78, 11 No. 4, pp. 292-305.

12 Isojeh, B., El-Zeghayar, M. and Vecchio, F. J., 2017, "High-cycle fatigue life prediction of 13 reinforced concrete deep beams," Engineering Structures, V. 150, pp. 12-24.

14 Kirkpatrick, J., Rankin, G. I. B. and Long, A. E., 1986, "The influence of compressive membrane 15 action on the serviceability of beam and slab bridge decks," The structural engineer, V. 64B, No. 1, 16 pp. 6-9.

17 Koekkoek, R. T., van der Veen, C. and de Boer, A., 2018, "Fatigue Tests on Post-tensioned Bridge 18 Decks," fib symposium 2017, Springer International Publishing, Maastricht, pp. 912-920.

19 Kuang, J. S. and Morley, C. T., 1992, "Punching shear behavior of restrained reinforced-concrete 20 slabs," ACI Structural Journal, V. 89, No. 1, pp. 13-19.

21 Kuang, J. S. and Morley, C. T., 1993, "A Plasticity Model for Punching Shear of Laerally 22 Restrained Slabs with Compressive Membrane Action," International Journal of Mechanical 23 Sciences, V. 35, No. 5, pp. 371-385.

24 Lantsoght, E. O. L., van der Veen, C., de Boer, A. and Walraven, J. C., 2013, "Recommendations 
2 Lantsoght, E. O. L., van der Veen, C. and de Boer, A., 2016, "Proposal for the fatigue strength of 3 concrete under cycles of compression," Construction and Building Materials, V. 107, No. 15 March $4 \quad 2016$, pp. 138-156.

5 Lantsoght, E. O. L., Yang, Y., van der Veen, C., de Boer, A. and Hordijk, D. A., 2017, "Beam 6 experiments on acceptance criteria for bridge load tests," ACI Structural Journal, V. 114, No. 4, pp. $7 \quad 1031-1041$.

8 Larson, K. H., Peterman, R. J. and Rasheed, H. A., 2005, "Strength-Fatigue Behavior of Fiber 9 Reinforced Polymer Strengthened Prestressed Concrete T-Beams," Journal of Composites for 10 Construction, V. 9, No. 4, pp. 313-326.

11 Lee, M. K. and Barr, B. I. G., 2004, "An overview of the fatigue behaviour of plain and fibre 12 reinforced concrete," Cement and Concrete Composites, V. 26, No. 4, 2004/05/01/, pp. 299-305.

13 Liu, F., Zhou, J. and Yan, L., 2018, "Study of stiffness and bearing capacity degradation of 14 reinforced concrete beams under constant-amplitude fatigue," PLOS ONE, V. 13, No. 3.

15 Low, A., 2011, "A Hole in Current Design Standards for Concrete Structures," IABSE Symposium, 16 London, UK.

17 Mander, J. B., Panthaki, F. D. and Kasalanati, A., 1994, "Low-Cycle Fatigue Behavior of 18 Reinforcing Steel," Journal of Materials in Civil Engineering, V. 6, No. 4, pp. 453-468.

19 Manfredi, G. and Pecce, M., 1997, "Low cycle fatigue of RC beams in NSC and HSC," 20 Engineering Structures, V. 19, No. 3, pp. 217-223.

21 Marshe, S. and Green, M. F., 1999, "Punching behaviour of composite bridge decks transversely 22 prestressed with carbon fibre reinforced polymer tendons," Canadian journal of civil engineering, 23 V. 26, No. 5, pp. 618-630.

24 Marthong, C., Dutta, A. and Deb, S. K., 2016, "Effect of Cyclic Loading Frequency on the 25 Behavior of External RC Beam-Column Connections," Journal of Earthquake Engineering, V. 20, 
2 Mitchell, A. D., Cook, W. D. and Dilger, W. H., 2005, "Effect of Size, Geometry and Mateiral

3 Properties on Punching Shear Resistance," ACI SP-232: Punching Shear in Reinforced Concrete

$4 \quad$ Slabs, pp. 39-56.

5 Muller, J. F. and Dux, P. F., 1994, "Fatigue of Prestressed Concrete Beams with Inclined Strands,"

6 Journal of Structural Engineering ASCE, V. 120, No. 4, pp. 1122-1139.

7 Naaman, A. E. and Founas, M., 1991, "Partially Prestressed Beams under Random-Amplitude

8 Fatigue Loading," Journal of Structural Engineering ASCE, V. 117, No. 12, pp. 3742-3761.

9 Noël, M. and Soudki, K., 2015, "Fatigue Behavior of Full-Scale Slab Bridge Strips with FRP

10 Reinforcement," Journal of Composites for Construction, V. 19, No. 2, pp. 04014047.

11 Oudah, F. and El-Hacha, R., 2013, "Research progress on the fatigue performance of RC beams 12 strengthened in flexure using Fiber Reinforced Polymers," Composites Part B: Engineering, V. 47, 13 2013/04/01/, pp. 82-95.

14 Regan, P. E. and Braestrup, M. W., 1985, "Punching Shear in Reinforced Concrete," CEB Bulletin $15168,241 \mathrm{pp}$.

16 Rodrigues, J. F. S., Casas, J. R. and Almeida, P. A. O., 2013, "Fatigue-safety assessment of 17 reinforced concrete (RC) bridges: application to the Brazilian highway network," Structure and 18 Infrastructure Engineering, V. 9, No. 6, pp. 601-616.

19 Salem, A., 2013, "Dynamic analysis and fatigue assessment of bridge decks subjected to traffic and 20 corrosion effects," M.S. Thesis, Colorado State University, Fort Collins, Colorado, pp. 119.

21 Saucedo, L., Yu, R. C., Medeiros, A., Zhang, X. and Ruiz, G., 2013, "A probabilistic fatigue model 22 based on the initial distribution to consider frequency effect in plain and fiber reinforced concrete," 23 International Journal of Fatigue, V. 48, Mar, pp. 308-318.

24 Schlafli, M. and Bruhwiler, E., 1998, "Fatigue of existing reinforced concrete bridge deck slabs," 25 Engineering Structures, V. 20, No. 11, pp. 991-998. 
1 Shahawi, M. E. and Batchelor, B. d., 1986, "Fatigue of Partially Prestressed Concrete," Journal of

2 Structural Engineering ASCE, V. 112, No. 3, pp. 524-537.

3 Sonoda, K. and Horikawa, T., 1982, "Fatigue strength of reinforced concrete slabs under moving

4 loads," V. 37, IABSE Reports.

5 Taylor, S. E., Rankin, B., Cleland, D. J. and Kirkpatrick, J., 2007, "Serviceability of bridge deck

6 slabs with arching action," ACI Structural Journal, V. 104, No. 1, January - February 2010, pp. 39-

748.

8 Teng, S., Ma, W., Tan, K. H. and Kong, F. K., 1998, "Fatigue tests of reinforced concrete deep

9 beams," The structural engineer, V. 76, No. 18, pp. 347-352.

10 Teworte, F. and Hegger, J., 2011, "Shear Fatigue of Prestressed Concrete Beams," IABSE 2011, pp. 118.

12 Teworte, F., Herbrand, M. and Hegger, J., 2015, "Structural Assessment of Concrete Bridges in 13 Germany - Shear Resistance under Static and Fatigue Loading," Structural Engineering 14 International, V. 25, No. 3, pp. 266-274.

15 Thomson, E., Bendito, A. and Flórez-López, J., 1998, "Simplified Model of Low Cycle Fatigue for 16 RC Frames," Journal of Structural Engineering, V. 124, No. 9, pp. 1082-1085.

17 Tien, S. C. and Clyde, E. K., 1958, "Static and Fatigue Strength in Shear of Beams with Tensile 18 Reinforcement," ACI Journal Proceedings, V. 54, No. 6.

19 Tilly, G.P., 1979, "Fatigue of steel reinforcement bars in concrete: a review," Fatigue \& Fracture of 20 Engineering Materials \& Structures, V. 2, No. 3, pp. 251-268.

21 Tilly, G. P., 1984, "Fatigue testing and performance of steel reinforcement bars," Matériaux et 22 Construction, V. 17, No. 1, January 01, pp. 43-49.

23 Tong, L., Liu, B., Xian, Q. and Zhao, X.-L., 2016, "Experimental study on fatigue behavior of Steel 24 Reinforced Concrete (SRC) beams," Engineering Structures, V. 123, pp. 247-262.

25 Tong, P. Y. and de Batchelor, B. V., 1972, "Compressive membrane enahncement in two-way 
bridge slabs," ACI SP 30-12, pp. 271-286.

2 Ueda, T., 1983, "Behavior in shear of reinforced concrete beams under fatigue loading," $\mathrm{PhD}$

3 Thesis, University of Tokyo, pp. 124.

4 van der Veen , C. and Bosman, A., 2014, "Fatigue strength of prestressed cast-in-between deck

5 panels (in Dutch)," Stevin Report nr. 25.5-14-06, 65 pp.

6 Walraven, J. C., 2002, "Background document for EC-2, Chapter 6.4 Punching Shear," Delft

7 University of Technology, Delft, The Netherlands, 16 pp.

8 Wang, H. L. and Song, Y. P., 2011, "Fatigue capacity of plain concrete under fatigue loading with

9 constant confined stress," Materials and Structures, V. 44, pp. 253-262.

10 Weisu, Y. and Thomas, T. C. H., 1995, "Fatigue Behavior of Steel Fiber Reinforced Concrete in

11 Uniaxial and Biaxial Compression," ACI Materials Journal, V. 92, No. 1, 1/1/1995.

12 Xin, Q., Dou, Y. and Chen, W., 2015, "Load Spectrum and Fatigue Life Computer Analysis of

13 Prestressed Concrete Bridges," 247-266 pp.

14 Xin, Q., Dou, Y. and Li, S., 2017, "Fatigue Behavior of Prestressed Concrete Beams under

15 Overload," 124-131 pp.

16 Younes, T., Al-Mayah, A. and Topper, T., 2017, "Fatigue performance of prestressed concrete

17 beams using BFRP bars," Construction and Building Materials, V. 157, 2017/12/30/,pp. 313-321.

18 Yu, R. C., Saucedo, L. and Ruiz, G., 2014, "A probabilistic fatigue model for quasi-brittle 19 materials," Advanced Materials Research, V. 875-877, pp. 1239-1242.

20 Yuan, M., Yan, D., Zhong, H. and Liu, Y., 2017, "Experimental investigation of high-cycle fatigue

21 behavior for prestressed concrete box-girders," Construction and Building Materials, V. 157, pp. $22 \quad 424-437$.

23 Zeng, D., Wang, G.-1., Xie, J. and Zheng, X.-h., 2014, "Exploratory Experimental Study on Fatigue 24 Prestress Loss of Prestressed Concrete Beams," Journal of Highway and Transportation Research 25 and Development (English Edition), V. 8, No. 2, pp. 37-41. 
1 Zhang, F., Ding, Y., Xu, J., Zhang, Y., Zhu, W. and Shi, Y., 2016a, "Shear strength prediction for 2 steel fiber reinforced concrete beams without stirrups," Engineering Structures, V. 127, No. 3 Supplement C, pp. 101-116.

4 Zhang, W., Liu, X. and Gu, X., 2016b, "Fatigue behavior of corroded prestressed concrete beams," 5 Construction and Building Materials, V. 106, pp. 198-208.

6

7 


\section{List of Tables}

3 Table 1 - Overview of static tests. Conversion: $1 \mathrm{kN}=0.225 \mathrm{kip}, 1 \mathrm{MPa}=145 \mathrm{psi}$

4 Table $2-$ Overview of fatigue tests. Conversion: $1 \mathrm{kN}=0.225 \mathrm{kip}, 1 \mathrm{MPa}=145 \mathrm{psi}$

5

Table 1 - Overview of static tests. Conversion: $1 \mathrm{kN}=0.225 \mathrm{kip}, 1 \mathrm{MPa}=145 \mathrm{psi}$

\begin{tabular}{|l|l|l|l|l|l|}
\hline Test number & $\begin{array}{l}\text { Size load } \\
(\mathbf{m m} \times \mathbf{m m})\end{array}$ & $\begin{array}{l}\boldsymbol{P}_{\max } \\
(\mathbf{k N})\end{array}$ & $\begin{array}{l}\text { Age } \\
(\mathbf{d a y s})\end{array}$ & $\begin{array}{l}\boldsymbol{f}_{\text {cm,cube }} \\
(\mathbf{M P a})\end{array}$ & Failure mode \\
\hline BB1 & $200 \times 200$ & 348.7 & 96 & 80.0 & $\mathrm{BP}$ \\
\hline BB2 & $200 \times 200$ & 321.4 & 99 & 79.7 & $\mathrm{BP}$ \\
\hline BB5 $^{*}$ & $200 \times 200$ & 490.4 & 116 & 79.2 & FP \\
\hline BB7 & $200 \times 200$ & 345.9 & 127 & 80.8 & BP \\
\hline BB16* & $200 \times 200$ & 553.4 & 186 & 81.2 & FP \\
\hline BB19 & $200 \times 200$ & 317.8 & 223 & 79.9 & BP \\
\hline BB24 & $200 \times 200$ & 330.0 & 326 & 79.9 & BP \\
\hline BB25** & $150 \times 115$ & 329.9 & 29 & 68.7 & BP \\
\hline BB27 & $150 \times 115$ & 364.6 & 62 & 76.9 & BP \\
\hline BB31 & $150 \times 115$ & 333.0 & 179 & 78.0 & BP \\
\hline
\end{tabular}

$7 \quad *$ Experiments with double wheel print

$8 * *$ Ducts of diameter $30 \mathrm{~mm}(1.2 \mathrm{in})$ at $300 \mathrm{~mm}$ (12 in) on center.

$9{ }^{1}$ Static test after fatigue test to $1,500,000$ cycles in which no failure occurred. 
Table 2 - Overview of fatigue tests. Conversion: $1 \mathrm{kN}=0.225 \mathrm{kip}, 1 \mathrm{MPa}=145 \mathrm{psi}$

\begin{tabular}{|c|c|c|c|c|c|c|}
\hline Test number & $\begin{array}{l}\text { Size load } \\
(\mathrm{mm} \times \mathbf{m m})\end{array}$ & $\begin{array}{l}F \\
(\mathbf{k N})\end{array}$ & $\boldsymbol{F} / \boldsymbol{P}_{\max }$ & $N$ & $\begin{array}{l}\text { Age } \\
\text { (days) }\end{array}$ & $\begin{array}{r}f_{\text {cm,cube }} \\
(\mathrm{MPa})\end{array}$ \\
\hline${\mathrm{BB} 17^{+}}^{+}$ & $200 \times 200$ & 275 & 0.80 & 13 & 147 & 82.6 \\
\hline${\mathrm{BB} 18^{+}}^{+}$ & $200 \times 200$ & 291 & 0.85 & 16 & 56 & 82.6 \\
\hline BB23 & $200 \times 200$ & 200 & 0.60 & 24,800 & 301 & 79.9 \\
\hline BB24 & $200 \times 200$ & 150 & 0.45 & $1,500,000$ & $307-326$ & 79.9 \\
\hline BB26** & $150 \times 115$ & 165 & 0.48 & $1,405,337$ & $35-59$ & $70.5-76.7$ \\
\hline \multirow[t]{3}{*}{ BB28 } & \multirow[t]{3}{*}{$150 \times 115$} & 165 & 0.48 & $1,500,000$ & $68-97$ & $76.8-77.1$ \\
\hline & & 200 & 0.58 & $1,000,000$ & $97-113$ & $77.1-77.3$ \\
\hline & & 240 & 0.70 & 7,144 & 113 & 77.3 \\
\hline \multirow[t]{2}{*}{ BB29 } & \multirow[t]{2}{*}{$150 \times 115$} & 200 & 0.58 & $1,500,000$ & $117-136$ & $77.3-77.5$ \\
\hline & & 220 & 0.64 & 264,840 & $136-139$ & $77.5-77.6$ \\
\hline \multirow[t]{5}{*}{ BB30* } & \multirow[t]{5}{*}{$150 \times 115$} & 280 & 0.58 & 100,000 & 143-144 & 77.6 \\
\hline & & 240 & 0.50 & $1,400,000$ & $144-162$ & $77.6-77.8$ \\
\hline & & 280 & 0.58 & 750,000 & $162-171$ & $77.8-77.9$ \\
\hline & & 320 & 0.67 & 500,000 & 171-177 & $77.9-78.0$ \\
\hline & & 360 & 0.75 & 32,643 & 177 & 78.0 \\
\hline \multirow[t]{2}{*}{ BB32 } & \multirow[t]{2}{*}{$150 \times 115$} & 240 & 0.70 & 10,000 & 184 & 78.1 \\
\hline & & 200 & 0.58 & 272,548 & $185-187$ & 78.1 \\
\hline
\end{tabular}

${ }^{+}$Tests with three cycles per load level

$4 \quad *$ Experiments with double wheel print

$5 \quad * *$ Ducts of diameter $30 \mathrm{~mm}(1.2 \mathrm{in})$ at $300 \mathrm{~mm}(12 \mathrm{in})$ on center.

6 


\section{$1 \quad$ List of Figures}

2 Fig. 1-Geometry of specimen: (a) side view showing prestressed girder (longitudinal) and

3 transverse beams (section) and loading frame; (b) top view showing four prestressed girders, three

4 deck panels, and loading frame; (c) side view showing a section of the slab-between-girder

5 structural system and loading frame. Conversion: $1 \mathrm{~mm}=0.04 \mathrm{in}, 1 \mathrm{~m}=3.3 \mathrm{ft}$.

6 Fig. 2- Photographs of setup. (a) Slab panel B ready for casting for additional fatigue tests. This

7 photograph shows the formwork, transverse prestressing ducts, mild steel reinforcement, and

8 remaining parts of the original test setup

9 Fig. 3-Numbering of tests: (a) original setup, including first series of static tests as reported by 10 Amir (2016); (b) setup with new slab panel B for fatigue tests.

11 Fig. 4-Loading scheme: (a) static test BB25; (b) tests with a low number of cycles BB17; (c) 12 fatigue tests, sinus load used for BB23.

13 Fig. 5-Specimen after failure: (a) static test BB25, (b) fatigue test BB26 with punching through of 14 load plate, (c) fatigue test BB30 with double wheel print, (d) saw cut of deck showing the ducts of 15 prestressing bars 26 - 30 (right to left) and punching cone of

16 Fig. 6-Development of cracks during BB29

17 Fig. 7-Resulting $S$ - $N$ curve from experiments. 

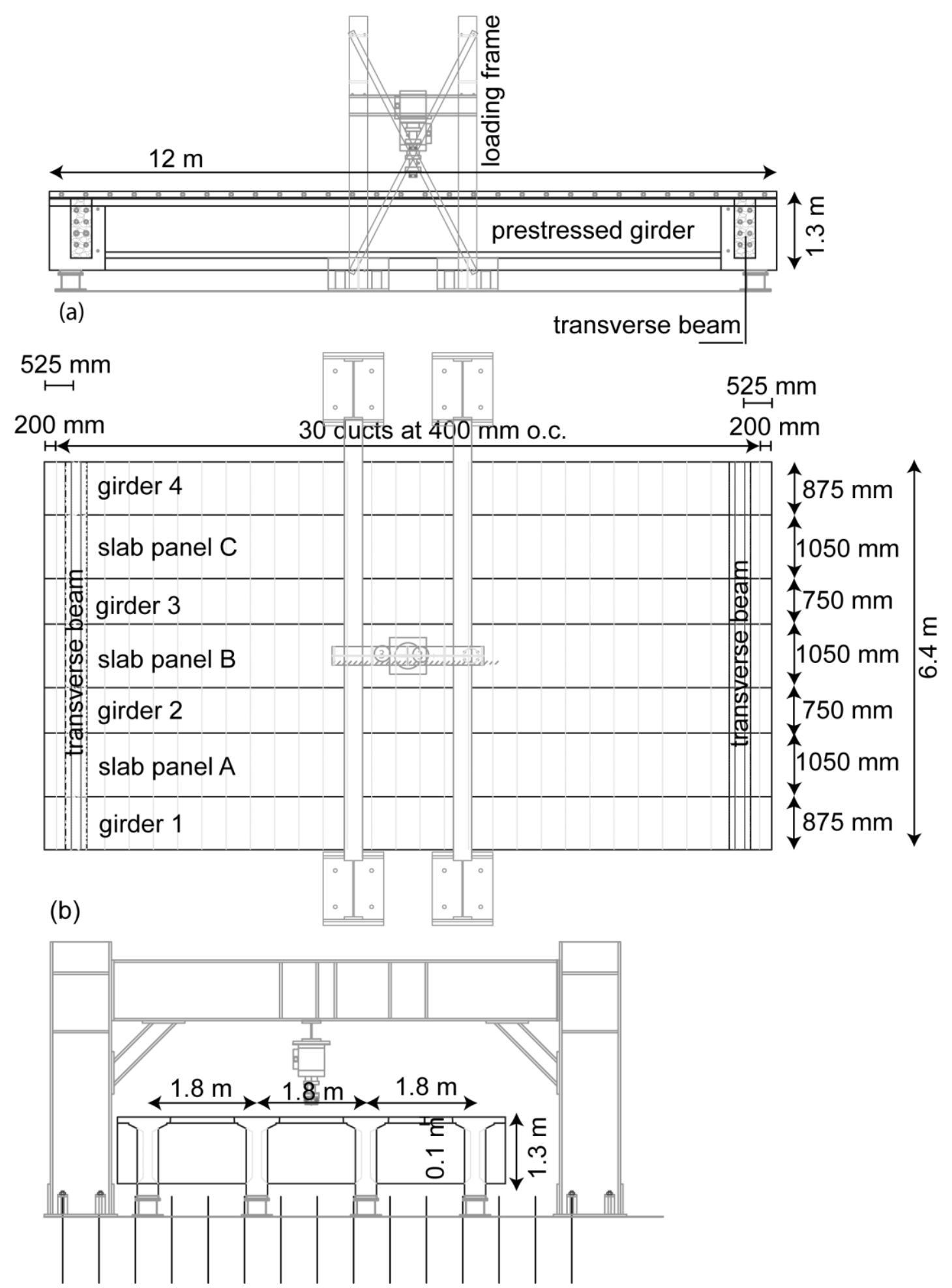

(c)

2 Fig. 1-Geometry of specimen: (a) side view showing prestressed girder (longitudinal) and

3 transverse beams (section) and loading frame; (b) top view showing four prestressed girders,

4 three deck panels, and loading frame; (c) side view showing a section of the slab-between-

5 girder structural system and loading frame. Conversion: $1 \mathrm{~mm}=0.04 \mathrm{in}, 1 \mathrm{~m}=3.3 \mathrm{ft}$. 


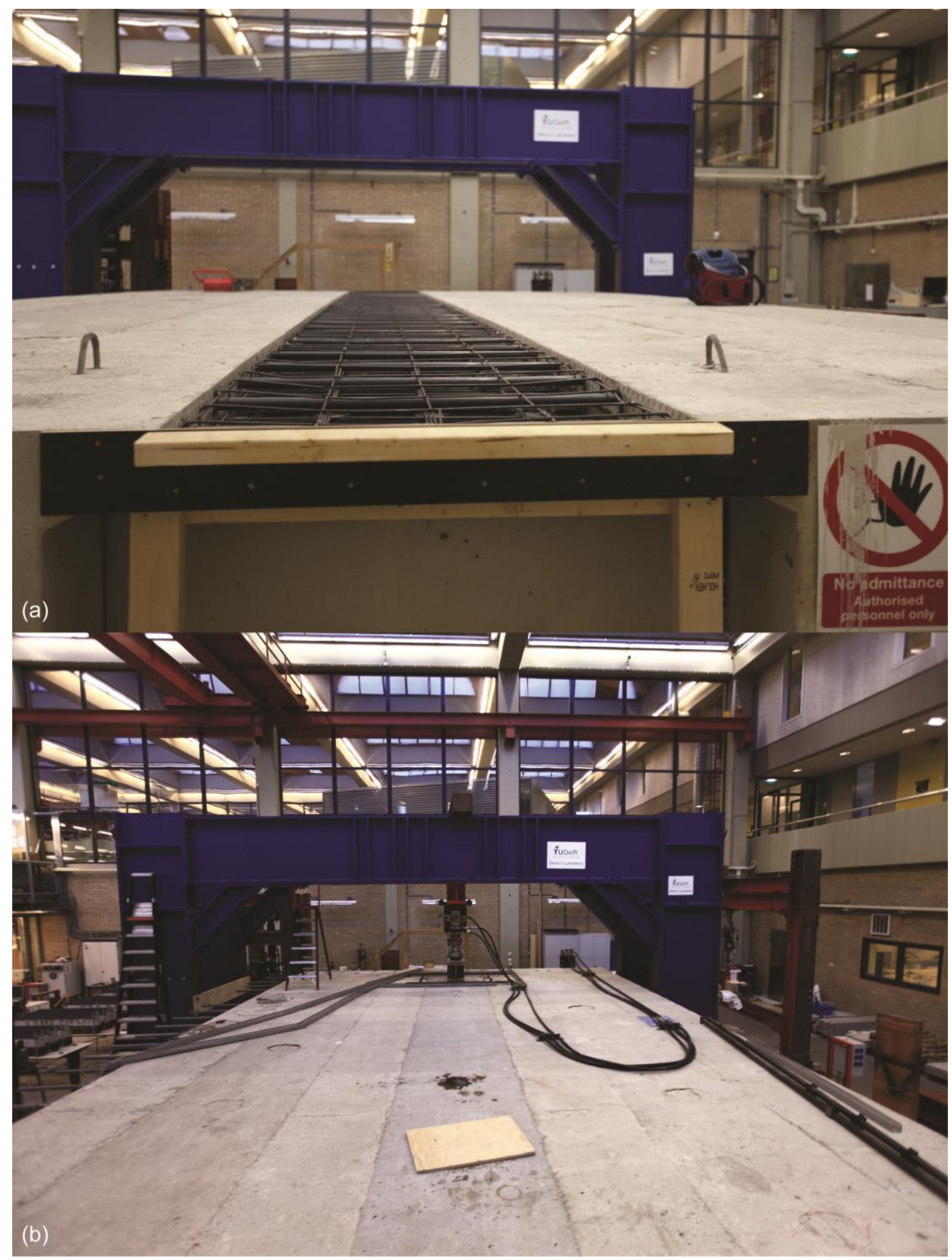

3 Fig. 2- Photographs of setup. (a) Slab panel B ready for casting for additional fatigue tests.

4 This photograph shows the formwork, transverse prestressing ducts, mild steel reinforcement, 5 and remaining parts of the original test setup. (b) Full test setup with new slab panel B. 


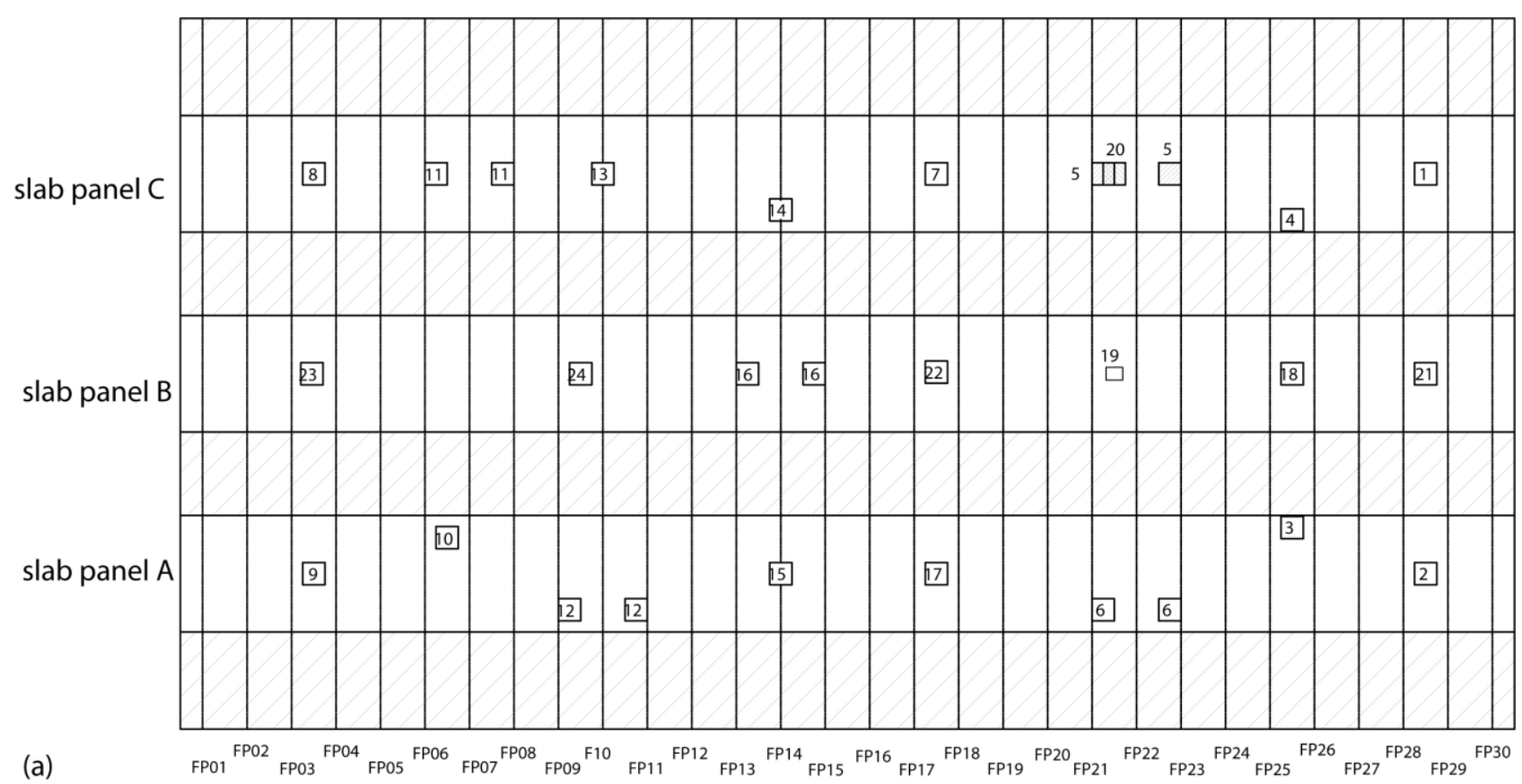

1 (b)

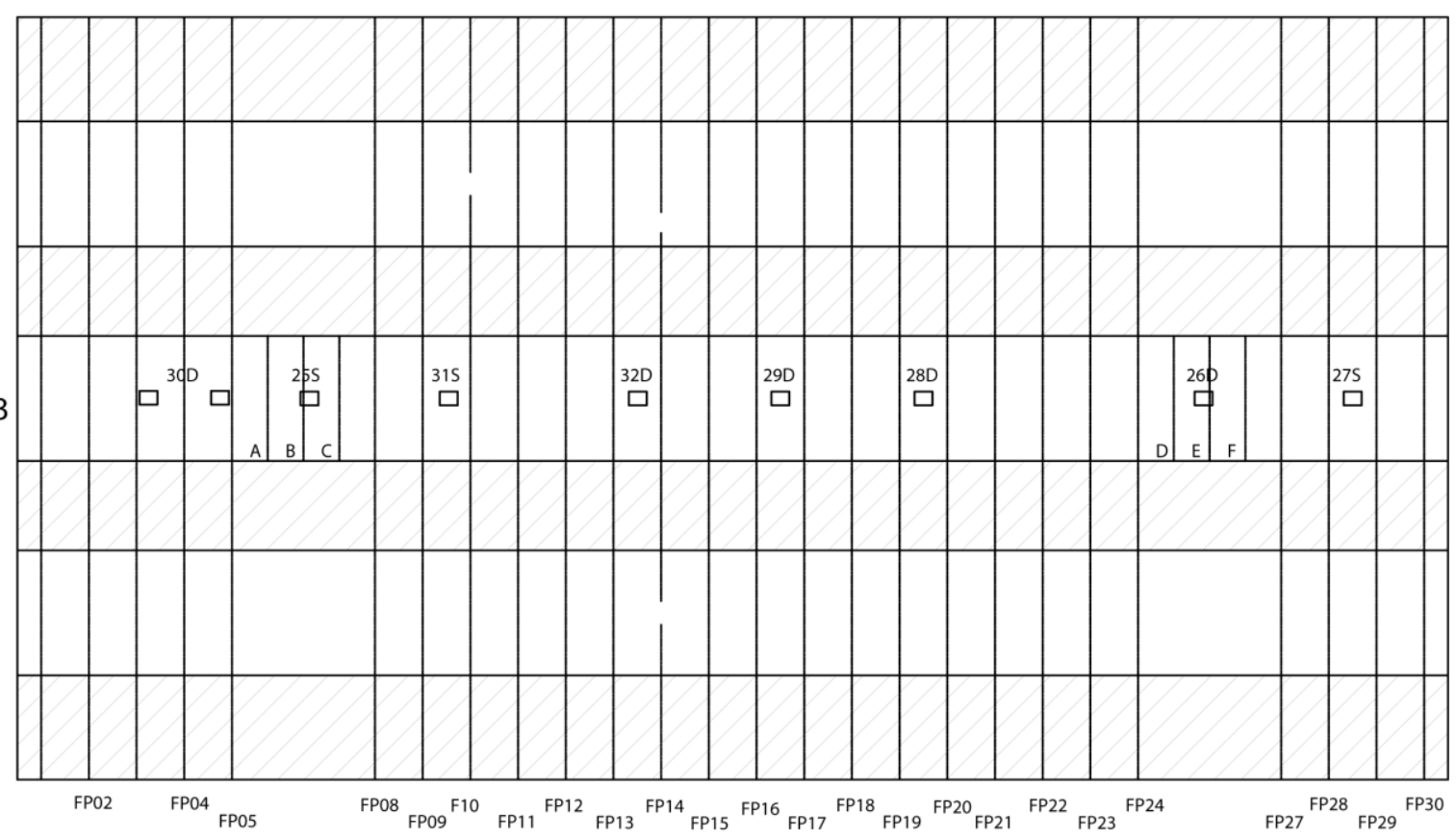

3 Fig. 3-Numbering of tests: (a) original setup, including first series of static tests as reported

4 by Amir (2016); (b) setup with new slab panel B for fatigue tests. For tests $25 S$ and 26D, the spacing between the ducts is smaller, as indicated with the centerlines of the prestressing bars. 

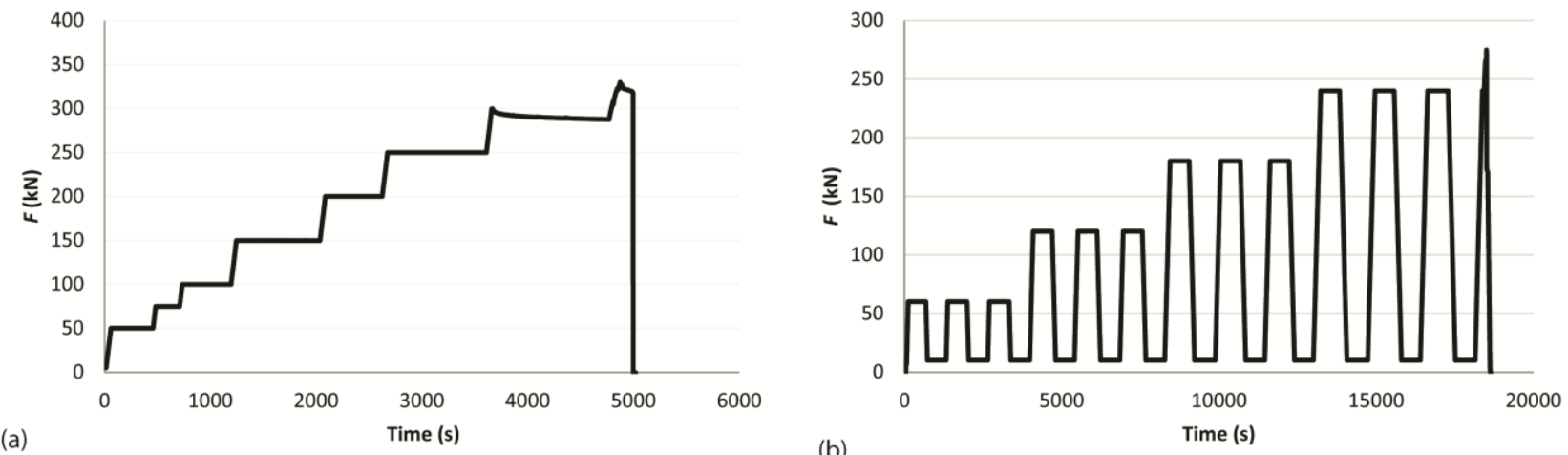

(a)

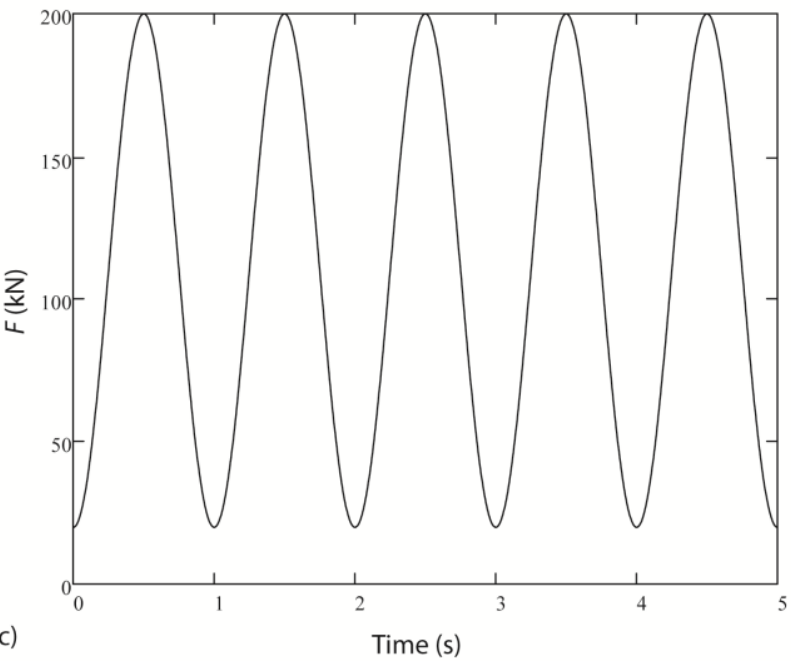

(b)

2 Fig. 4-Loading scheme: (a) static test BB25; (b) tests with a low number of cycles BB17; (c)

3 fatigue tests, sinus load used for BB23. 


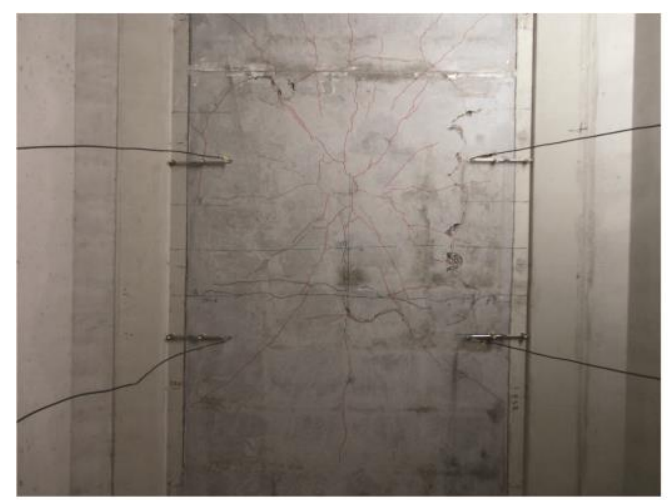

(a)

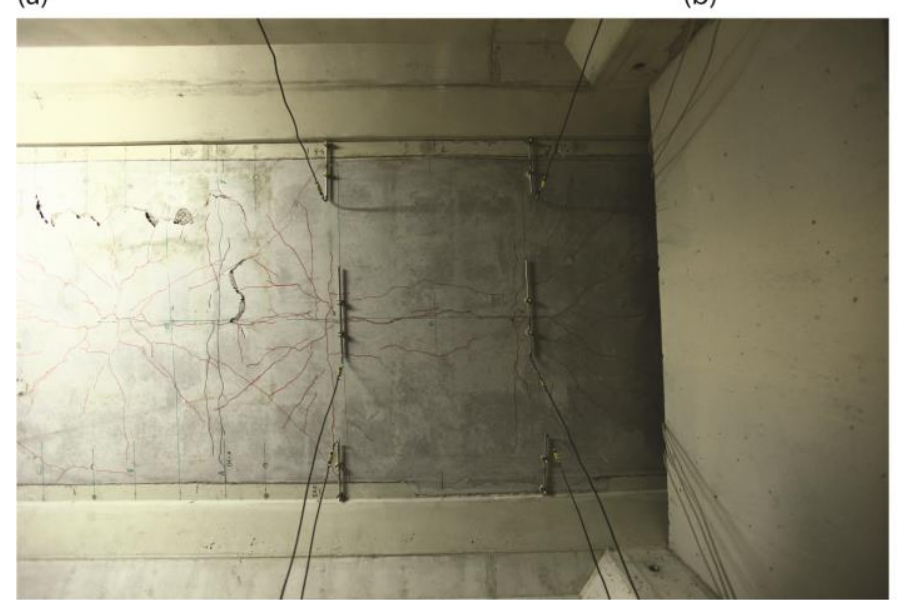

(c)

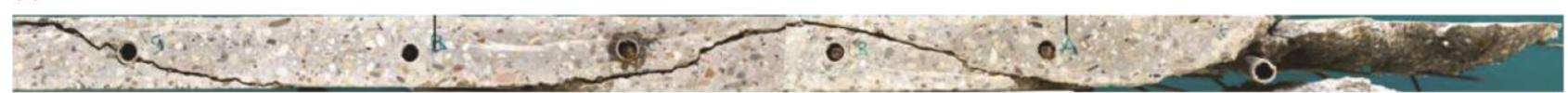

(d)

2 Fig. 5-Specimen after failure: (a) static test BB25, (b) fatigue test BB26 with punching

3 through of load plate, (c) fatigue test BB30 with double wheel print, (d) saw cut of deck

4 showing the ducts of prestressing bars 26 - 30 (right to left) and punching cone of BB27.

5

6 

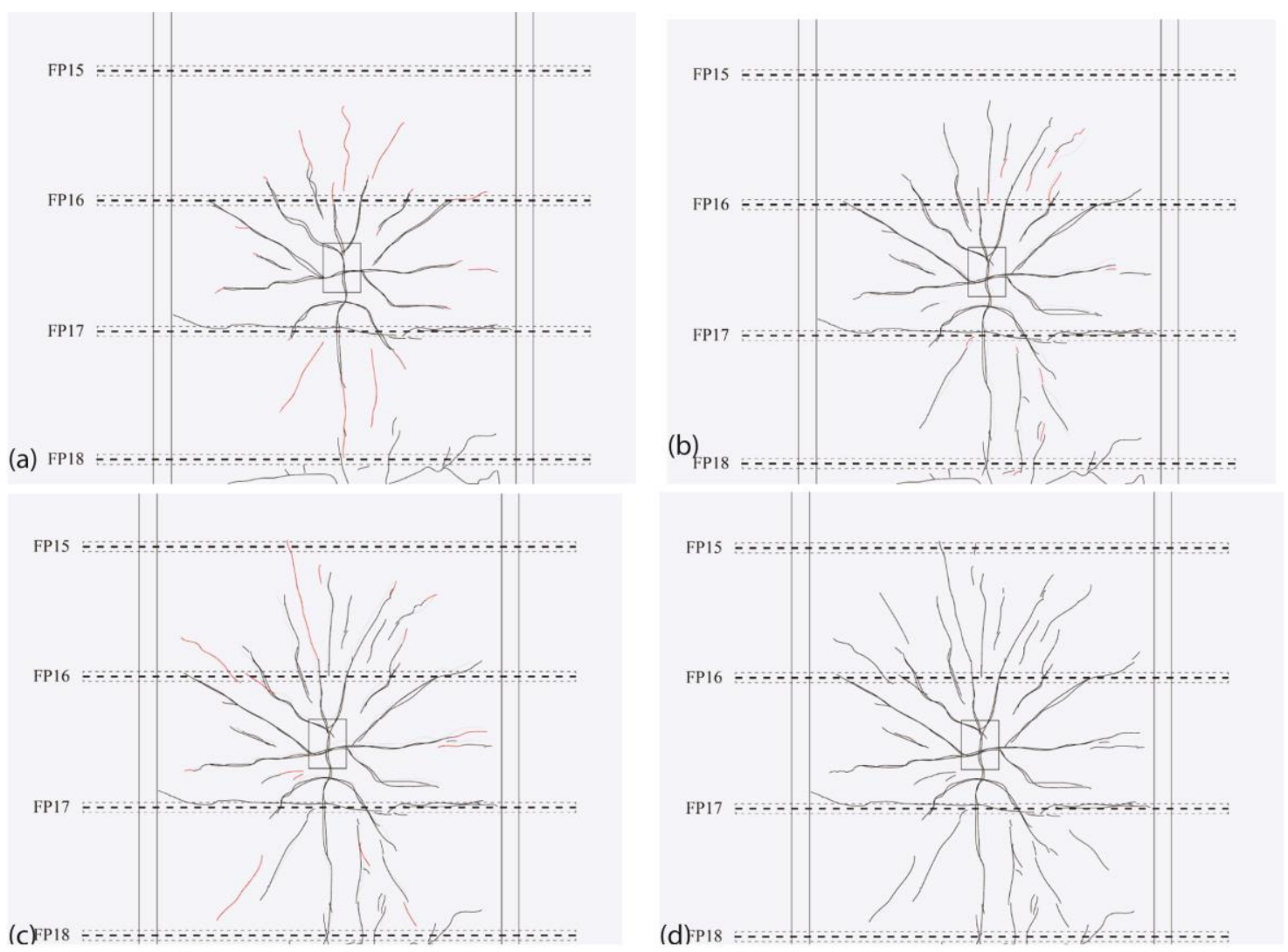

2 Fig. 6-Development of cracks during BB29: (a) after 1,000 cycles; (b) after 100,000 cycles; (c) 3 after 500,000 cycles; (d) after 1,500,000 cycles.

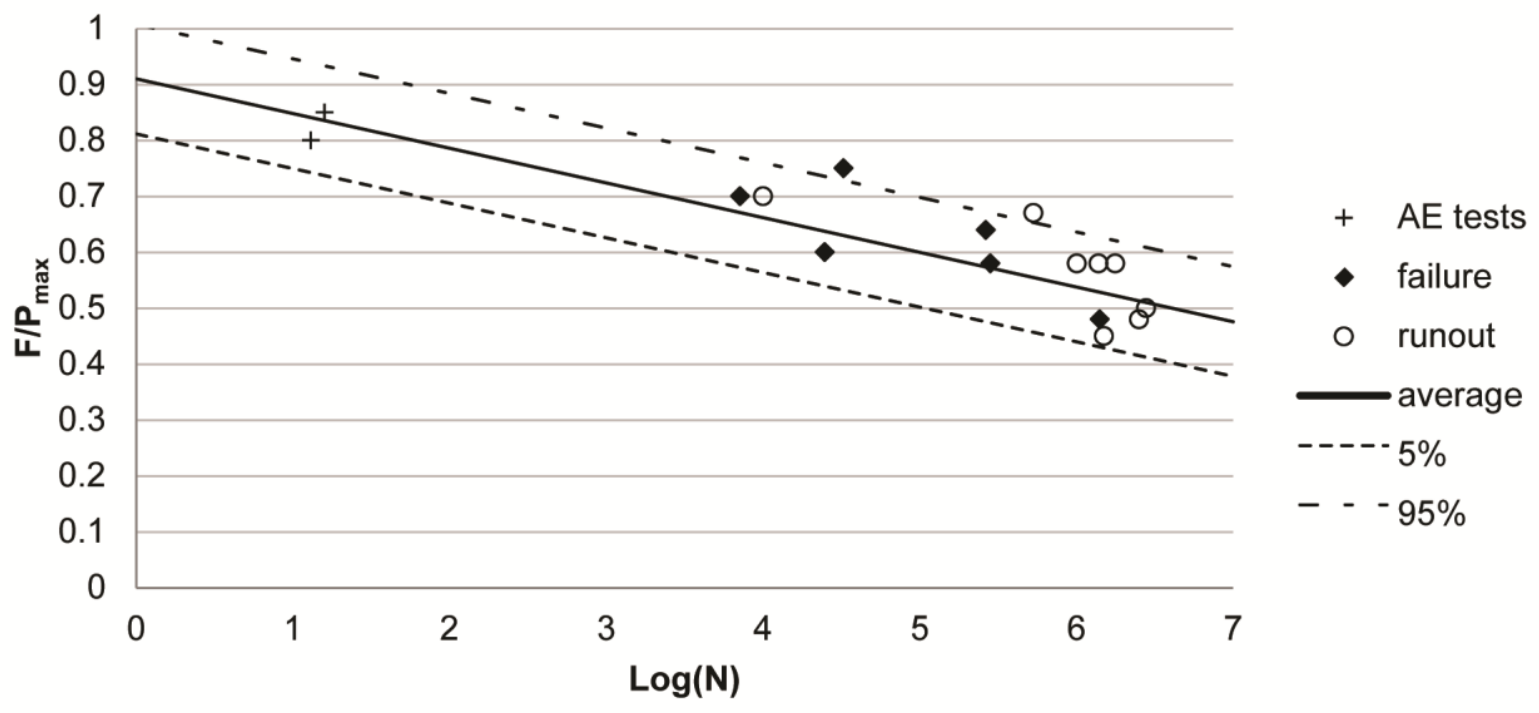

4

Fig. 7-Resulting $S-N$ curve from experiments. 